\title{
The Effect of Compensation on Employees Performance at Badan Pengelolaan Keuangan dan Aset Daerah Office in Luwu Regency
}

\author{
Herman $^{1}$, M. Risal ${ }^{2}$, Sapar $^{3}$ \\ \{herman@student.umpalopo.ac.id, mrisal@umpalopo.ac.id, sapar@umpalopo.ac.id\} \\ Postgraduate of Management, Universitas Muhammadiyah Palopo \\ Jalan Jendral Sudirman Km. 3. Binturu Kota Palopo, 91922, Indonesia
}

\begin{abstract}
This research was quantitative study that aimed to determine the effect of compensation on employee performance at Badan Pengeloaan Keuangan dan Asset Daerah Office in Luwu Regency (Empirical Study at Dinas Pendapatan Pengelolaan Keuangan dan Aset Daerah Luwu Regency). The number of samples in this study were 95 respondents. The sample collection method used questionnaires as a data collection tool. To determine the data, whether valid or not, it was used a validity test using Person Product Moment while the reliability test used Cronbach Alpha. The data analysis technique used was simple linear analysis. All data obtained were tested by using $t$ test, correlation coefficient test $(\mathrm{R}$ test) and Determinant test (R2). Based on the results of data analysis, it can be concluded that the compensation variable has a significant effect on the performance of Badan Pengelolaan Keuangan dan Asset Daerah Office in Luwu Regency to explain the variation in the total and budgeted compensation variables. The compensation variable has a relationship to the performance variable.
\end{abstract}

Keywords: compensation, employee performance

\section{Introduction}

A company or organization has rules for granting compensation to the employees. The method of providing compensation to employees can be adjusted to the conditions owned by the company so that the company is not affected by the environmental situation both internally and externally such as the community around the company, the environment of the company itself, the insistence of employees on wage increases. Every company has rules that can be applied to manage employees. As well as company policy in terms of setting compensation for employees so that the organizational goals of company can be achievedi.[1]

The policy of providing additional income allowance (compensation) is expected to improve employee welfare so that it is expected to encourage increased employee performance.[2]

Employees who have good performance should receive an award given by the company or organization to employees who have high productivity of their work. Awards received by employees are awards given based on the performance produced, the company must not do favoritism for high-performing employees with low-performing employees for the awards to be given, therefore, in order not to cause jealousy in working the company must be honest . The facilities are the provision of salary and remuneration based on their work. [3]

In general, employees compensation is divided into four types of compensation, namely: salary/wages, time wage system, bonuses, and incentive. Compensation is given to employees because the company has assessed that compensation is given to employees who have high work 
performance. Compensation ensures fairness in working for the rights granted to outstanding employees by following the procedures established by the company, employees who receive compensation will further improve their quality well and maintain the achievements given by the company.

Improved performance will have a very important meaning for employees to continuemaking improvements so the organizational goals are achieved. Human resources have a strategic role that must be realized in order to improve the quality and role of employees to create a framework for achieving organizational goals. Motivation is needed for every employee to encourage employees to have good performance in finishing their jobs.

Based on these descriptions, the researcher interested in conducting research under the title "Effect of Compensation on Employee Performance at Badan Pengelolaan Keuangan Dan Aset Daerah Office in Luwu Regency". Then the formulation of the problem in this study can be formulated: how the effect of compensation on employee performance at the office of the financial management agency and regional assets of the Luwu district

\section{Literature Review}

Compensation includes all types of payments either directly or indirectly, in the form of material/money or awards given by the company to its workers/laborers. One of the important element in the company's management system besides work motivation and compensation is leadership. [4]

Compensation Indicator [5] indicators of compensation are as follows:

a) The salary received by the employee, is an obligation of the giver to give in a defeated manner and is still paid every month for employees who work, both work full time, do not come for some reason, then the fixed salary must be paid in full.

b) Incentives are a form of appreciation for employees who are motivated to work well so that they are productive and creative, but the time is not fixed..

c) Bonuses can be interpreted as additional income by finishing work well so the employee can get an extra paid.

d) Wages are paid to employees because they have extra working hours.

e) Premium is the amount of money given to employees, gifts, benefits obtained as a form of concern for the employee so that it must be paid at a certain time both normal and abnormal circumstances.

f) Treatment is protection given to employees, families of employees who have an accident or disaster, so the company has responsibility to help.

g) Insurance is an action that is given to an insured employee, where the employee has lost the benefits of a third party that occur at an uncertain time.

Increased employee performance is an important factor in the progress of the company or organization because it has human resources. The success of company is the main goal caused by high performance employees so that the goals of company are achieved, but the company may experience setbacks due to low employee performance so the company is unable to maintain the business. Good performance employees certainly have high motivation, and otherwise the poor performance employees will have low motivation and it can make companies or organizations lose reputation in society. The explanation above needs careful attention so that employee performance can be improved. [6]

Individual employee performance indicators can be measured by 6 different criteria [7], namely: 
1. Work quality is measured by the achievements of employees who work and produce quality work so that it can be measured that the employee has skills.

2. Quantity is the amount produced by employees from the results of work performed to produce the number of jobs that increase due to good performance employees.

3. Timeliness, the level of completion of work on time that is stated with perfect work results without getting criticized for improvement.

4. Effectiveness is the level of time usage at work so that the spending time can be more efficient because of technology, raw materials, labor, and money can be maximized to increase the amount of resources.

5. Independence, the ability of an employee to do work without asking for help from co workers, so that it can produce more output without superiors monitoring.

6. Work commitment, the attitude of an employee towards their commitment at work so they have high responsibility for their work.

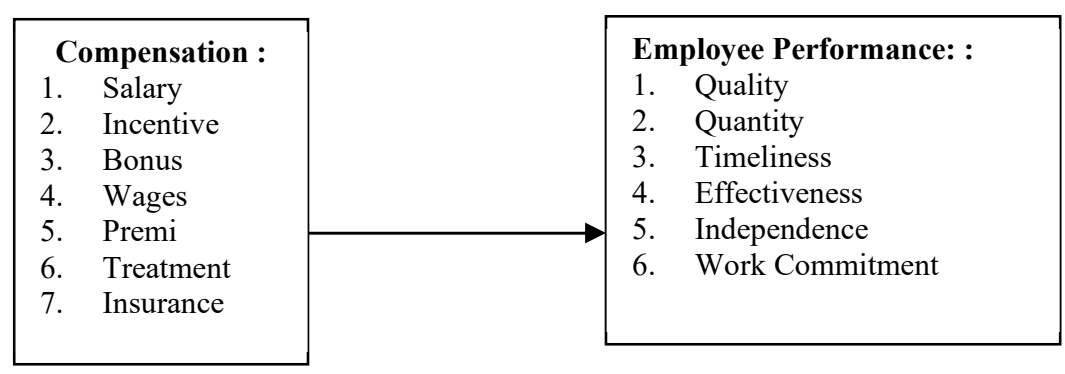

Fig.1. Conceptual Framework

Based on the conceptual framework, the hypothesis in this study we can conclude: it is suspected that compensation has a positive effect on employee performance.

\section{Method}

This research was a type of research that was explained the relationship between research variables by analyzing the indicators on each variable measured. Therefore this type of research is called Explanatory research. This study explained the effect of compensation on employee performance at Badan Pengelolaan Keuangan dan Aset Daerah of Luwu Regency. The sample in this study were 95 as respondents.

Data is collected through distributing questionnaires to respondents, then the data collected will be analyzed using SPSS statistical tools with simple regression techniques where the previous data was tested for validity and reliability. 


\section{Result And Discussion}

The analysis used in this study was simple linear regression. The analysis was used to show the influence of independent variables, namely compensation $(\mathrm{X})$ on the dependent variable, namely employee performance (Y).

Table 1. Coefficients ${ }^{\mathrm{a}}$

\begin{tabular}{|c|c|c|c|c|c|c|}
\hline \multirow{2}{*}{\multicolumn{2}{|c|}{ Model }} & \multicolumn{2}{|c|}{$\begin{array}{c}\text { Unstandardized } \\
\text { Coefficients }\end{array}$} & \multirow{2}{*}{$\begin{array}{c}\text { Standardized } \\
\text { Coefficients } \\
\text { Beta }\end{array}$} & \multirow[t]{2}{*}{$\mathrm{t}$} & \multirow[t]{2}{*}{ Sig. } \\
\hline & & $\mathrm{B}$ & Std. Error & & & \\
\hline & (Constant) & 23.794 & 3.266 & & 7.286 & .000 \\
\hline 1 & $\begin{array}{l}\text { Compensation } \\
\text { (X) }\end{array}$ & .090 & .105 & .097 & .851 & .397 \\
\hline
\end{tabular}

a. Dependent Variable: Work Performance (Y)

According to the calculation of a simple linear regression analysis the equation can be as follows: $\mathrm{Y}=\mathrm{a}+\mathrm{bx}$ or $\mathrm{Y}=23.79+0.090+\mathrm{e}$

Simple linear equations were explained with a variable $\mathrm{X}$ regression coefficient of 0.090 which states that each 1 percent increase in compensation will affect the increase in employee performance (Y) is positive. This is supported by research conducted [8],[9],[10], and [11], which explained that compensation, motivation, leadership, competence and job satisfaction have positive influences on employee performance.

Table 2. Model Summary

\begin{tabular}{ccccc}
\hline Model & $\mathrm{R}$ & R Square & Adjusted R Square & Std. Error of the Estimate \\
\hline 1 & $.867^{\mathrm{a}}$ & .633 & .671 & 1.218 \\
\hline
\end{tabular}

\section{a. Predictors: (Constant), Compensation (X)}

Based on the calculation, the coefficient of determination (Adjusted R2) is 0.671. This means that the magnitude of the variable employees performance of Badan Pengelolaan Keuangan dan Aset Daerah Office in Luwu Regency that can be explained by variations in compensation variables is 67.1 percent while the remaining 32.9 percent is influenced by other factors.

\section{Conclusion}

Data is collected through distributing questionnaires to respondents, then the data collected will be analyzed using SPSS statistical tools with simple regression techniques where the previous data was tested for validity and reliability. 


\section{Acknowledgments}

Dr. Muhammad Aqsa, S. Kom. M. Si., For knowledge and guidance so that this article can be finished.

\section{References}

[1] Riana N, Fajri K, Alsyaumi K. Pengaruh Kompensasi Terhadap Kinerja Karyawan Di Kampung Batu Malakasari Tektona Waterpark Kabupaten Bandung. Tour Sci J 2017; 2: 1.

[2] Pontoh F. Pengaruh Kompensasi Dan Beban Kerja Terhadap Kepuasan Kerja Dan Dampaknya Pada Kinerja Pegawai Pada Badan Perencanaan Pembangunan Daerah Propinsi Sulawesi Tengah. Katalogis 2014; 2: 101-113

[3] Unud EM. Fakultas Ekonomi dan Bisnis Universitas Udayana, Bali , Indonesia ABSTRAK Manusia sebagai faktor utama dalam setiap kegiatan organisasi merupakan asset yang unik, karena dalam pengelolaannya begitu banyak faktor yang mempengaruhi dan sangat sulit untuk . 2017; 6: 33703397.

[4] Riyadi S. Pengaruh Kompensasi Finansial, Gaya Kepemimpinan, dan Motivasi Kerja Terhadap Kinerja Karyawan pada Perusahaan Manufaktur di Jawa Timur. J Manaj dan Kewirausahaan; 13. Epub ahead of print 2011. DOI: 10.9744/jmk.13.1.40-45.

[5] Rotua Situmorang SN, Sarjono H. Pengaruh Motivasi Kerja dan Kompensasi Terhadap Kepuasan Kerja serta Dampaknya pada Kinerja Pegawai Negeri Sipil Kantor Kecamatan Kebon Jeruk, Jakarta Barat. J Ekon Univ Esa Unggul 2013; 4: 17910.

[6] Setiawan F, Dewi A. Pengaruh Kompensasi Dan Lingkungan Kerja Terhadap Kinerja Karyawan Pada Cv. Berkat Anugrah. E-Jurnal Manaj Univ Udayana 2014; 3: 252522.

[7] Kurniawan, Indra dan Santoso. 2012. Analysis Of Effect Of Leadership, Discipline Of Work, Work And Motivation For Employee Performance PT. Prima Zirang Main Semarang. Dinamika Manajemen Vol. 1 No. 2 | Halaman 79-88.

[8] Giarti, Yuni. 2013. The Influence Of Compensation, Field Work, Leadersip And Organizational Culture Toward (A Case Study CV. Arirang Management Semarang). Q-MAN Vol. 2 No. 7 Halaman 33-48.

[9] Yahyo, Djoko, Handoyo W dan Dewi, Reni Shinta. 2013. Pengaruh Motivasi, Lingkungan Kerja, Dan Kompensasi Terhadap Kinerja Karyawan Melalui Semangat Kerja Karyawan (Studi Kasus Pada Karyawan Bagian Produksi CV. Putra Jaya Sahitaguna, Semarang). Diponegoro Journal Of Social And Politic Tahun 2013, Hal. 1-12 http://ejournal-s1.undip.ac.id/index.php/.

[10] Widyatmini dan Hakim, Luqman. 2008. Hubungan Kepemimpinan, Kompensasi, dan Kompetensi Terhadap Kinerja Pegawai Dinas Kesehatan Kota Depok. Jurnal Ekonomi Bisnis No. 2 Vol. 13, Agustus 2008 : 163-170.

[11] Retnaningsih, Sudarwanti. 2007. Analisis Pengaruh Keadilan Kompensasi, Peran Kepemimpinan, dan Kepuasan Kerja Terhadap Komitmen Organisasi Dalam Meningkatkan Kinerja Karyawan (Studi Kasus: Pada Sentral Pengolahan Pos Semarang). Tesis : Program Studi Magister Manajemen Program Pasca Sarjana Universitas Diponegoro Semarang. 